Сзерський М.P., кандидат історичних наук, старший викладач кафедри Високомобільних десантних військ $i$ Сил спеціальних операщуій НУО України імені Івана Черняховського (м. Київ);

Кришній П.І., старший викладач кафедри Високомобільних десантних військ $і$ Сил спеціальних операчій НУО України імені Івана Черняховського (м. Київ)

\title{
ОРГАНИ КЕРІВНИЦТВА ПАРТИЗАНСЬКИМИ СИЛАМИ У РОКИ ДРУГОЇ СВІТОВОЇ ВІЙНИ (1941-1945)
}

У статті узагальнено заходи щчодо організащџї партизанських сил, розглянуто органи керівнищтва партизанським рухом у роки Другої світової війни та розкрито їх завдання. Доведено, що партизанська боротьба $\epsilon$ характерною рисою прогнозованих воєнних конфліктів і має бути складовою воєнної стратегії держави та концепиії забезпечення ї̈ національної безпеки. Разом з тим розглянуто структуру партизанських формувань деяких країн Східної Свропи.

Ключові слова: організація партизанських сил, органи керівництва, партизанські формування, рух Опору, партизанська боротьба.

Особливістю Другої світової війни став широкий антифашистський рух Опору, що розгорнувся в багатьох країнах окупованих гітлерівською Німеччиною та іï союзниками. Найефективнішою формою цього Опору став партизанський рух. Досвід локальних війн і збройних конфліктів повоєнного періоду засвідчив значну роль дій партизанських формувань (формувань руху Опору) на окупованих противником територіях. Уряди країн, що стали на шлях прогресивних соціальних перетворень, і країн, що можуть піддатися нападу агресора, мають завчасно готуватися до ведення партизанської війни, 
бо в сучасних війнах часу на підготовку партизанських сил і засобів буде обмаль. Для організації такої підготовки доцільно заздалегідь створити компетентні органи для керівництва партизанською боротьбою. Це - складові у справі загальної підготовки країни до ведення партизанської війни. Досвід ведення партизанської боротьби (В’єтнам, Афганістан, Таджикистан, Чечня) свідчіть, що рух Опору є невід'ємною складовою переважної більшості воєнних конфліктів кінця XX - початку XXI ст. У широкому розумінні рух Опору - це боротьба народних мас за свободу і незалежність своєї країни, що ведеться на окупованій (анексованій, тимчасово зайнятій) противником (агресором) території. Тому дослідження досвіду організації руху Опору, набутого в роки війни та збройних конфліктів, має особливу актуальність.

В історичній i мемуарній літературі радянського періоду (1945-1991рр.) вийшли спеціальні дослідження та збірки статей, де наведені дані з організації партизанського руху на окупованій радянській території. Проте в узагальнюючих працях 3 історії Другої світової війни організація та керівництво партизанським рухом на окупованій ворогом території висвітлені в загальному плані. Часткове відображення організації діяльності партизанів і підпільників розкрито у виданні “Украинская ССР в Великой Отечественной войне Советского Союза” [20], у працях В. Боярського [2; 3; 4], В. Клокова [10; 11], П. Пономаренка [15], А. Попова [16], І. Старинова [18], В. Бистрова [19] та інших.

3 кінця 1980-х - початку 1990-х років активізувалося вивчення бойових дій, розвитку воєнного мистецтва, партизанського руху та переосмислення перебігу війни. Доступ українських істориків до спецфондів архівів сприяв появі нових наукових і науково-довідкових праць, зокрема А. Кентія, В. Лозицького [6; 7; 21], А. Кентія, В. Лозицького, М. Слободянюка [8], І. Кураса, А. Кентія [9], В. Кучера, О. Потильчака [13], М. Рибака, І. Печенюка [14; 17; 24], А. Чайковського [23] та ін. Дослідники підкреслюють, що партизани зробили суттєвий внесок у справу Перемоги в складних умовах війни та довели стратегічне значення партизанської боротьби у військовій теорії і практиці. У 
сучасній історіографії відбувається переосмислення низки положень радянських дослідників, розкриваються малодосліджені аспекти організації партизанської боротьби (руху Опору), поступово формується нова система уявлень про дії партизанів на території України. Тому виникає потреба в уточненні завдань, що покладалися на структурні підрозділи Українського штабу партизанського руху (УШПР) з організації партизанських формувань та керівництва ними.

Метою статті є узагальнення досвіду організації партизанських сил i керівництво ними.

Уперше в історії війн питання про створення органів керівництва партизанськими силами, що мали б стратегічне значення у визвольних війнах, було поставлене В. Леніним ще під час революції 1905-1907 pp. У подальшому, в роки Громадянської війни з метою здійснення керівництва партизанськими силами на первинному етапі боротьби з внутрішніми та зовнішніми ворогами Радянської республіки при оперативному відділі Народного комісаріату військових і морських справ (НКВіМС) було створено Центральний штаб партизанських загонів (ЦШПЗ) [4, с. 49-50; 11, с. 5-6]. Цей штаб після укладення Брестського миру перейменували на Особливе розвідувальне відділення (ОРВ). ЦШПЗ, а пізніше ОРВ розробляв і надавав до оперативного відділу НКВіМС свої пропозиції щодо організації партизанських формувань i ïx бойового застосування. При ОРВ була організована спеціальна партизанська школа, де навчалися не лише курсанти, а й партизани, які прибували з тилу противника, та повстанці. У другій половині 20-х - першій половині $30-\mathrm{x}$ років ХХ ст. Комуністична партія і Радянський уряд, враховуючи можливість нової війни, створили спеціальні відділи у складі Генштабу Червоної армії та ОДПУ СРСР, а на місцях, у штабах прикордонних військових округів і ОДПУ були створені спеціальні відділи (відділення). Ці структурні підрозділи розробляли мобілізаційні плани розгортання і ведення партизанської війни у разі агресії ймовірних противників Радянського Союзу, займалися підготовкою партизанських командних кадрів і нових технічних засобів. Взаємодія органів управління 
партизанською боротьбою була настільки тісною, що спільні навчання проводилися за єдиним планом, удосконалювалися засоби і способи боротьби. На випадок війни по лінії Наркомату оборони були сформовані, навчені i перевірені на військових навчаннях штаби i партизанські організаторські групи, які, по суті, були основою майбутніх партизанських бригад і корпусів, здатних швидко перерости в партизанські армії. Поруч із західними кордонами СРСР для них закладали матеріальні засоби.

У роки німецько-радянської війни 1941-1945 років до створення органів військового керівництва партизанськими силами у масштабах усієї країни деякі ЦК компартій і навіть обкоми партій союзних республік, яким загрожувала окупація, самі створювали керівні оперативні групи. Про масштаб роботи, виконаної партійними органами з організації партизанської боротьби у ворожому тилу на початку війни, свідчать такі дані. За офіційною радянською статистикою станом на 1 жовтня 1941 р. на окупованій на той час території України було створено 738 партизанських загонів (за різними даними 26257 осіб) і 191 диверсійна група (1374 бійці) [14, с. 108; 24, с. 98]. Сучасна статистика свідчить про загальну чисельність у 27631 особу (близько 50-60\% із них були комуністами і комсомольцями). Але, на жаль, як виявилося, більшість партизанських загонів існувала лише на папері. У вересні-грудні 1941 p. основними осередками партизанської активності були північні райони Сумської, Чернігівської, Київської та Житомирської областей, лісовий масив поблизу Черкас, болотиста місцевість у пониззі Дніпра поблизу Нікополя, невеликі лісові масиви Полтавщини, де реальною силою, здатною завдавати відчутних втрат ворогові, залишалися кілька великих загонів і з'єднань [5, с. 127].

Таким чином, уже в перші тижні війни вищі ешелони радянської влади заклали основи організованого партизанського руху на окупованій території СРСР, політичне та ідеологічне керівництво яким взяла на себе комуністична партія. У ході війни завдання партизанської боротьби визначилися рішеннями ЦК ВКП(б) або ж постановами Державного Комітету Оборони (ДКО). Крім того, завдання ставились у наказах НКО СРСР і Ставки Верховного 
Головнокомандування (ВГК), а конкретизувалися органами партизанського руху відповідно до завдань збройних сил та умов партизанського руху у визначених районах. У зв'язку з розширенням партизанської боротьби і накопиченням бойового досвіду партизанам доручали значно ширші та більш конкретні завдання.

Дуже важливу роботу під керівництвом ЦК ВКП(б) 3 організації партизанських загонів, що формувалися, їх озброєнню, постачанню та організації зв'язку з діючими партизанськими формуваннями проводили органи НКВС, Головне розвідувальне управління, Головне політичне управління Червоної армії і Військові ради фронтів та армій.

Головне розвідувальне управління Червоної армії формувало, готувало $\mathrm{i}$ засилало в тил противника розвідувальні і диверсійні групи (загони), багато 3 яких надали велику допомогу місцевим партизанським формуванням. У цілому, органи армійської розвідки і НКВС всебічно допомагали партійним органам формувати, навчати і матеріально забезпечувати партизанські загони i диверсійні групи, створювати партизанські бази [2, с. 22-25]. Проте Центральний штаб партизанського руху (ЦШПР), штаби партизанського руху при Військових радах фронтів були створені рішенням ЦК ВКП(б) лише 30 травня 1942 р. Фактичне керівництво партизанськими силами України до зазначеного часу здійснювало 4-е управління НКВС УРСР, а $з 29$ червня УШПР (створений постановою ДКО) набув більшої самостійності, маючи головним об’єктом своєї діяльності окуповану територію України [17, с. 103].

Досвід організації партизанського руху у Другій світовий війни показав, що органи керівництва партизанською боротьбою виконували такі основні завдання, як: вивчення противника і його ймовірні контрпартизанські заходи, соціально-політичні і географічні умови, в яких вестиметься партизанська війна; підбір, підготовка командних i технічних кадрів; створення організаторських, підпільних і партизанських формувань; удосконалення засобів і методів боротьби; розроблення нових, найсучасніших і зручних для партизанів малогабаритних диверсійних i технічних засобів зв'язку; 
розроблення планів операцій i організація їх всебічного забезпечення; управління діями партизанських сил; ведення політичної роботи серед населення, партизанів і збройних сил противника; організація постійного управління партизанськими силами; створення та закладка відповідним чином запасів матеріальних засобів.

Для організації партизанської боротьби, створення нових партизанських загонів, безпосереднього керівництва партизанськими формуваннями у великих операціях і для координації їхніх дій УШПР створював і направляв у ворожий тил групи, а саме: емісарські, організаторів партизанського руху, організації партизанських загонів, керівників партизанських загонів, організаторські (основа майбутнього партизанського формування), десантні, оперативні, фахівців партизанської боротьби (підривників, радистів, аеродромного забезпечення та ін.), спеціальні, розвідувальні (розвідувально-диверсійні), диверсійні (диверсійнорозвідувальні), кур'єрів для зв'язку з партизанськими загонами. Так, зокрема на емісарські групи покладалися такі завдання, як: виявлення самовідданих прихильників соціалістичного будівництва та організація партизанських загонів 3 їх числа; встановлення зв'язку 3 партизанськими загонами, передавання настанов щодо координації їх бойових дій; інформування керівництво УШПР про бойові операції загонів, 3 якими встановлений зв'язок; проведення роз'яснювальної роботи; організація зовнішньополітичної розвідки; встановлення зв'язку 3 діючими партизанськими загонами в районі дій та координація їх діяльності.

Групи організації партизанських загонів виконували, в основному, такі завдання: відновлення зв'язку 3 діючими партизанськими загонами; активізація дій загонів, що діяли у підпіллі, і тих, що припинили свою діяльність; створення нових партизанських загонів за рахунок місцевого населення; організація бойових дій і диверсій на комунікаціях; створення партизанських баз; збирання розвідувальних даних; політична робота серед населення на окупованій території; знищення зрадників і шпигунів. 
Організаторські групи, по суті, були основою майбутніх партизанських формувань, здатних вести боротьбу на певних напрямах. Такі організаторські групи могли діяти не лише на окупованій противником території, а й за кордоном. При цьому особливий акцент робився на диверсійнорозвідувальну діяльність [15, с. $28 ; 22$, с. 18-24, 34, 36, 62, 72].

Основною організаційною формою партизанських сил у роки Другій світовій війни був партизанський загін, що складався з кількох бойових груп, взводів, рот, а інколи й батальйонів. Загони діяли як самостійно, так і в складі з'єднань (бригад і навіть дивізій). Зазвичай загони базувалися окремо один від іншого i, залежно від обстановки, діяли за завданням командування з'єднання самостійно або спільно. Разом з тим діяли окремі групи, партизанські бригади та з'єднання. Єдиної організаційно-штатної структури партизанських формувань не було, оскільки їхня чисельність і озброєння залежали від умов, в яких вони діяли, та набутого досвіду їх організаторів. Однак в основу організації усіх партизанських формувань була покладена військова організація і військова дисципліна. 3 офіцерів Червоної армії і НКВС переважно комплектувався постійний склад партизанських шкіл, керівний і оперативний склад штабів партизанського руху [17, с. 104].

У роки національно-революційної війни в Іспанії партизанські формування створювалися за схемою, розробленою і перевіреною в СРСР на початку 1930-х років. Зокрема, структура 14-го партизанського корпусу, що у жовтні 1937 р. діяв в Іспанії, по суті, була аналогічною радянському партизанському корпусу, а влітку 1938 р. - радянській партизанській армії, що призначалася для дій у Румунії на випадок розгортання війни проти СРСР [5, с. $101 ; 18$, с. 105-106, 109-110].

Диверсійні дії в Іспанії здійснювали як невеликі (5-10 осіб), так i значно потужніші (50-100 осіб) загони. У ворожий тил їх виводили пішим порядком через лінію фронту. Тривалість дій таких загонів становила від 10 діб до 3 місяців. На першому етапі війни перевагу надавали невеликим групам, а згодом і великим загонам. У подальшому їх об'єднали у 14-й 
(партизанський) корпус, що підпорядковувався розвідувальному відділу Республіканської армії. Основою для створення партизанського корпусу стала організаторсько-диверсійна група, до складу якої входив військовий радник Радянського союзу І. Г. Старінов. Враховуючи ненадійність і громіздкість переносних радіостанцій, їх невелику кількість, радіозв'язок 3 групами практично не використовували. Розвідувальні дані командири груп доповідали після повернення з тилу противника. Станом на початок 1938 р. склад корпусу нараховував до чотирьох дивізій і трьох-чотирьох загонів (бригад), чисельністю від 150 до 200 осіб у кожному. На Каталонському фронті діяла одна дивізія. Три дивізії були в центральній зоні: в Андалузії, Естремадурі і на Центральному фронті. Там перебувала і більша частина радянських радників [1, с. 243].

Частини корпусу продовжували діяти і після падіння партизанської республіки, але вже після того основні сили перейшли у Францію, звідки були інтерновані. Інші морем пішли до Алжиру, а потім і в СРСР. Чисельні диверсійні прийоми, відпрацьовані в ході громадянської війни в Іспанії, згодом були використані в різних державах у різні часи.

У роки Другої світової війни в Югославії уже 27 червня 1941 р. був створений Головний штаб народно-визвольних партизанських загонів Югославії на чолі з І. Броз Тіто, що пізніше, під час створення Народновизвольної армії Югославії, був реорганізований у Головний штаб Народновизвольної армії і партизанських загонів.

Партизанською боротьбою у Франції керував Національний військовий комітет партизанів i франтирерів. Організаційна структура франтирерів і Французьких партизанських сил (ФТПФ; $\not p$. Les Francs-Tireurs et Partisans français - FTPF) була дуже своєрідна. Традиційно самостійно діючі франтирери (вільні стрілки) об’єднувалися в невеличкі команди по тричотири особи. Дві такі команди складали бойову групу - первинну одиницю ФТПФ. До неї входили сім бійців і командир. Для забезпечення безпеки група розділялася на дві команди по чотири особи в кожній. Головну 
команду очолював командир групи, команду підтримки - заступник командира групи. Командир особисто контактував із трьома бійцями 3 головної команди, а через свого заступника - з бійцями команди підтримки. Обидві команди збиралися тільки для проведення операцій, a після ii виконання знову розділялися. Це правило було обов’язковим тільки для партизанів, які діяли в містах. При цьому ті, хто воював у містах, отримували зброю лише на час проведення операції. Потім зброю здавали, а бійці знову ставали цивільними особами, як інші городяни. Ніхто не мав знати місце проживання будь-якого бійця, навіть командир групи [1; 12].

До кінця 1942 р. групи стали об’єднувати в загони, в кожному по тричотири бойові групи. Командирові загону допомагали два заступники: перший відповідав за особовий склад, організацію, вербування і моральний стан особового складу, інший - за технічні питання, озброєння, розвідку і фізичний стан бійців, а також за постачання. Командир і заступники не звільнялися від участі в операціях [12].

Коли три-чотири загони діяли в одній, порівняно обмеженій зоні, вони могли утворювати роту. Командирові роти допомагали два заступники: по особовому складу і з технічних питань, які підбирали співробітників для “штабного взводу” роти. По мірі розвитку партизанської боротьби в ротах створювалися й інші підрозділи. Це залежало від наявності видів озброєння.

В останні місяці 1943 р., коли розпочався масовий приплив людей, які тікали від німецької “трудової повинності”, в силах французького руху Опору стали створюватися взводи, роти і батальйони, що провели перші бойові операції у квітні 1944 р. У проміжках між бойовими операціями усі батальйони (роти) розсіювалися з метою конспірації по різних населених пунктах так, щоб ї чисельність в одному такому населеному пункті не перевищувала 30 осіб, зберігаючи здатність швидко зосередитися знову. Такі формування об'єднувалися територіально по департаментах i групах департаментів. Один-два департаменти утворювали “район”. Силами району командував Районний військовий комітет (РВК). Декілька таких районів 
утворювали “міжрайон” на чолі 3 Міжрайонним військовим комітетом (МРВК). Національний військовий комітет керував діяльністю усіх МРВК, іноді через “командувача областю”, що об’єднувала декілька районів. Зв’язок забезпечували спеціальні агенти, які не мали прямого контакту 3 бійцями $[1 ; 12]$.

У лютому $1944 \mathrm{p}$. франтирери i партизани увійшли до складу об'єднання Французьких внутрішніх сил (ФФI; $\not p p$. Forçes Françaises de l'Intérieure - FFI), зберігши свою організаційну самостійність. На момент збройного повстання 1944 р. чисельність франтирерів і партизанів досягла 250 тис. осіб (майже половину від загальної чисельності ФФІ). Після визволення Франції франтирерів, партизанів і ФФІ розпустили, а їх бійців частково включили до регулярної армії [12].

Аналогічно були організовані партизанські сили, тільки під іншими назвами, у Бельгії, Голландії, Італії, Польщі, переважно у великих містах або в густонаселеній місцевості, 3 досить розвиненою мережею доріг. Така організаційна структура не втратила свого значення і після Другої світової війни та в сучасних умовах. Прикладом цьому служить організаційна структура партизанських формувань у Південному В'єтнамі, Бразилії, Алжирі та інших країнах, народи яких боролися проти реакційних режимів i колонізаторів.

Отже, партизанська боротьба, що притаманна сучасним “малим війнам” та $€$ характерною рисою прогнозованих воєнних конфліктів, має стати складовою воєнної стратегії держави та концепції забезпечення іiі національної безпеки, складовою політики з проблем військового будівництва. Як показав історичний досвід, при підготовці до партизанської боротьби органи керівництва партизанськими силами мають бути здатними організовувати розвідку, підбирати і готувати кадри, забезпечувати партизанські сили потрібними засобами, організовувати надійне управління. Такий орган керівництва має обов'язково функціонувати ще до початку ведення партизанських дій. 
Одночасно для ведення “малих війн” необхідні високомобільні, багатофункціональні компоненти збройних сил країн, що здатні діяти рішуче та швидко проти регулярних та іррегулярних сил противника у відриві від своїх головних сил і баз постачання в умовах, коли важко провести межу між станом війни і миром, між військовими операціями та злочинними акціями, між тилом i фронтом. Партизанська боротьба проти агресора i проти антинародних реакційних режимів як стратегічний засіб потребує завчасної організації та всебічної підготовки партизанських сил і матеріальних засобів.

\section{Список використаних джерел і літератури}

1. Александровская С.М. Мы - интернационалисты... - М.: Политиздат, 1975. - 285 с.

2. Боярский В.И. Правильная “неправильная” война. - М. : Изд. дом "Граница", 2013. - 320 с.

3. Боярский В.И. Партизанская война: История утраченных возможностей / В.И. Боярский. - Мн. : Харвест; М. : АСТ, 2001. - 304 с.

4. Боярский В.И. Партизанство вчера, сегодня, завтра. Историкодокументальный очерк. - М. : Изд. дом “Граница”, 2003. - 448 с.

5. Война в тылу врага. О некоторых проблемах истории советского партизанского движения в годы Великой Отечественной войны. - М. : Политиздат, 1974. - Вып. 1. - 447 с.

6. Кентій А., Лозищький $B$. Війна без пощади i милосердя: Партизанський фронт у тилу вермахту в Україні (1941-1944). - К. : Генеза, 2005. $-408 \mathrm{c}$.

7. Кентій А.В., Лозищький В.С. Радянські партизани 1941-1944: світло й тені. - К., 2010. - 80 c.

8. Кентій А.В, Лозищький В.С. Слободянюк М.А. Радянський рух Опору на окупованій території України. - К. : Ін-т історії України НАН України, 2010. -98 c. 
9. Курас И.Ф., Кентий А.В. Штаб непокоренных (Украинский штаб партизанского движения в годы Великой Отечественной войны). - К. : Политиздат Украины, 1988. - 330 с.

10. Клоков В.И. Всенародная борьба в тылу немецко-фашистских оккупантов на Украине. 1941-1944: историографический очерк. - К. : Изд-во “Наукова думка”, 1978. - 124 с.

11. Клоков B.I. Исторические тетроди. О стратегии и тактике советских партизан в борьбе против фашисиских окупантов на Украине (1941-1944). - К. : Вид-во Академії наук Української РСР, 1994. - 236 с.

12. Колосков И.А., Цырульников Н.Г. Народ Франции в борьбе против фашизма. - М., 1960.

13. Кучер B.I., Потильчак О.В. Україна 1941-1944: трагедія народу 3 фасадом Священної війни : монографія. - К.; Біла Церква: ТОВ “Білоцерківдрук”, 2011. - 368 с.

14. Печенюк I.C., Печенюк C.I. До 120-річчя від дня народження Сидора Ковпака // Воєнна історія. - 2007. - № 1-3 (33-34). - С. 107-115.

15. Пономаренко П.К. Всенародная борьба в тылу немецко-фашистских захватчиков 1941-1944. - М. : Наука, 1986. - 439 с.

16. Попов А.Ю. НКВД и партизанское движение. - М.: ОЛМАПРЕСС, 2003. - 383 c.

17. Рибак M.I., Печенюк I.C. Партизанська боротьба в Україні та іiі стратегічне значення // Воєнно-історичний вісник. - 2012. - Вип. 2 (4). C. $98-115$.

18. Старинов И.Г. Мины замедленного действия. - М. : Альманах “Вимпел”, 1999. - 288 с.

19. Советские партизаны. Из истории партизанского движения в годы Великой Отечественной войны / Сост. В.Е. Быстров. - М. : Госполитиздат, 1961. $-831 \mathrm{c}$. 
20. Украинская ССР в Великой Отечественной войне Советского Союза 1941-1945 гг.: В 3 т. - К. : Политиздат Украины, 1975. - Т. 1. - 544 с. - Т. 2. 512 c. - T. 3. -563 c.

21. Україна партизанська. Партизанські формування та органи керівництва ними (1941-1945 рр.): наук.-досвід. вид. / Авт.-упоряд.: О. В. Бажан, А. В. Кентій, В. С. Лозицький та ін. ; Редкол: В. А. Смолій та ін. - К. : Парламентське вид-во, 2001. - 319 с.: іл.

22. Центральний державний архів громадських об'єднань України, ф. 62, оп.1, спр.78, арк. 168.

23. Чайковський А.С. Невідома війна (Партизанський рух в Україні 19411944 pр. мовою документів, очима історика). - К., 1994. - 256 с.

24. Честь і слава Батьківщини. - К. : ТОВ “Брама-V”, 2011. - 352 с. 
Yezerskyi M.R., Candidate of Historical Sciences, Senior Lecturer of Department of Highmobile landings troops and Special Operations Forces of Ivan Cherniakhovskyi National Defence University of Ukraine (Kyiv);

Kryshnii P.I., Senior Lecturer of Department of High-mobile landings troops and Special Operations Forces of Ivan Cherniakhovskyi National Defence University of Ukraine (Kyiv)

\section{MANAGEMENT BODIES OF THE GUERRILLA FORCES DURING THE SECOND WORLD WAR (1941-1945)}

The article summarizes for the organization of guerrilla forces, guerrilla management bodies during the Second World War were considered and their objectives revealed. It is proved that guerrilla struggle is a feature of predicted military conflicts and should be an integral part of the military strategy of the state and the concept of ensuring its national security. At the same time, the structure of the guerrilla formations of some Eastern European countries is considered.

Keywords: organization of guerrilla forces, management bodies, guerrilla formations, resistance movement, guerrilla fight. 